\title{
Privileges and Obligations of Academic Status
}

\author{
By ARTHUR M. McANALLY
}

DURING the past twenty-five years, most colleges and the majority of universities have recognized the essentially academic nature of the work of professional librarians by granting them academic or faculty status. This movement towards closer identification of librarians with traditional faculty has required a progressive reorientation of library thought and practices as librarians have tended more and more to apply to themselves the truly academic criteria which the classroom faculty apply to themselves.

The application of faculty standards to librarians has required adaptations and interpretations to fit the special circumstances of librarians. Therefore it has seemed desirable to the Committee on Academic Status ${ }^{1}$ to state these principles and interpretations, particularly for the benefit of those academic libraries whose professional staffs only recently have achieved this recognition. The privileges and obligations of academic status fall logically into three categories: general considerations of interest to librarians, library administrators, and university administrators; obligations of library administrators; and the newer duties of librarians. All factors intermingled are described below.

1. The academic viewpoint. Professional librarians must accept in principle the standards, customs, and regulations governing the faculty of their institution. These factors, while uniform in principle nationally, may vary in detail at different

\footnotetext{
1 These interpretations of academic status for librarians were drafted for the Committee on Academic Status of the University Libraries Section of the Association of College and Research Libraries and have been approved as statements of policy by the committee. Members of the committee are Lewis C. Branscomb, R. B. Downs, William H. Jesse, Archie L. MeNeal, and Arthur M. McAnally, chairman.
}

Dr. McAnally has been Director of $\mathrm{Li}$ braries at the University of Oklahoma, Norman, since 1951, and was Director of the Library School there until 1960.

institutions; the local practices should prevail.

2. Composition of the staff. Library staffs should consist of two distinct and different groups: first, professional librarians possessing academic status who perform duties of an educational and research character, which require professional training for competent performance; and second, a staff of supporting clerical and other nonprofessional personnel who perform under supervision the more elementary and routine tasks. It is recognized that the proportion in each group will vary with the character, the organization, and, especially, the size of libraries.

3. Qualifications of professional librarians. All new appointees should possess appropriate academic qualifications (including advanced professional degrees, plus other degrees for certain positions), intellectual curiosity, and sound personality. It is recognized that in large libraries some specialists such as archivists may need specialized degrees.

4. Professional librarians should be eligible for appointment to the traditional ranks and titles of instructor, assistant professor, associate professor, and professor.

5. Recruitment. In recruiting new librarians, usual academic practices should be followed. If it is customary at the individual institution to hold formal interviews with candidates for appointment to higher ranks, then the library 
administration should hold similar interviews. To these should be invited both librarians and other academic people who might be interested, such as members of the faculty library committee.

\section{Staff participation in government. If} the classroom faculty at an institution utilize the committee system in conducting certain departmental and college affairs, then the library should do likewise.

7. Faculty library committee. The library as a general educational agency should make use of an advisory faculty committee.

8. Criteria for considering for salary adjustment, promotions in rank, and granting of tenure. These criteria vary between college and university, from institution to institution, and in the emphasis given to each. Practices of the individual institution should be followed. The commonly used criteria and library interpretations of each are:

a) Success in teaching. It should be recognized that the librarian's own job is a full-time counseling and teaching responsibility of a special kind. Teaching shall be interpreted to mean the kind of teaching, either group or individual, direct or indirect, that a professional librarian does. Success in teaching shall be interpreted to mean successful performance of assigned library duties.

It should be recognized that much library service to students and faculty is on an informal and individual basis, and also that some library activities, while very important to the development and use of library resources and requiring high levels of academic competence, may not involve direct contacts with students at all.

b) Research or creative work. These should be encouraged and rewarded. However, it must be recognized that since librarians usually must work thirty-nine or forty hours a week or more to perform their tasks successfully, librarians have less time and energy for research than classroom faculty. Time off for research projects should be allowed if possible. High-level administrative studies should be recognized.

c) Professional competence and activity. These are as important to the ongoing quality of library work as for teaching. Time off for attendance at professional meetings and travel allowances should be available.

d) University and public service. Librarians need to be active in these areas. It should be recognized that as relatively new members of the academic team, librarians may not have many opportunities for service on university committees for some years.

e) Administrative services. Nearly all librarians have some administrative duties, if no more than supervision of nonprofessional and student assistants. Where the librarian has major administrative duties, this factor becomes important in review for promotion or salary adjustment, and the success of this unit should be the general measure of effectiveness.

9. Academic rank independent of administrative rank. Just as for the classroom faculty, promotions in rank or salary should not be conditioned upon advances in, or performance of, administrative duties. Thus a teacher of Greek might advance through the ranks from instructor to full professor without regard to whether or not he ever serves as chairman or head of his department. Similarly, librarians should be advanced when appropriate without regard to the proportion of administrative work performed.

10. Tenure. Librarians should be eligible for tenure. The conditions and procedures for granting tenure should be 
patterned after other faculty practices, with modifications as necessary.

When academic status is first granted to the librarians of an institution, the existence of de facto tenure for older members of the library staff should be recognized without a waiting period. However, tenure in such cases should not be automatic.

11. Academic freedom. Librarians should have the same privileges of academic freedom as the classroom faculty, and also must accept the corresponding responsibilities. This freedom has special application to library resources. Librarians shall have freedom to choose, and shall protect faculty rights to choose, any materials deemed desirable for their work and shall provide access to all library materials without undue restrictions. In protecting the freedom to read, librarians should have the safeguards afforded to the classroom faculty.

12. Sabbatical leaves. Librarians should be entitled to the privileges of sabbatical leave, if an institutional practice, and should be encouraged to make wider use of the opportunity for growth and renewal that this privilege offers. Chief librarians have special obligations to facilitate this professional activity.

13. Sanctity of contract. A contract of employment once offered and accepted must be honored, by both the institution and the individual, for ethical and legal reasons. Librarians should not ask to be relieved of contract obligations except at the close of the regular academic year and always should give adequate advance notice.

14. Twelve-month salaries. When librarians are offered twelve-month appointments, instead of the nine-month appointment usual for the classroom faculty, an equitable adjustment should be made in their salaries.

15. Classroom teaching. Librarians should be allowed to teach formal classes in library science, bibliography of a subject, or other areas closely related to their regular duties when this can be done without reducing the effectiveness of their regular library work. Time off must be provided for such teaching proportional to the amount of full-time teaching that the class represents. A librarian should not be allowed to teach more than one course a semester.

16. Distribution among ranks. An equitable distribution of librarians among the different academic ranks should be sought. It is noted that the distribution tends to be poor where academic status has been in effect a relatively short time.

17. Rank of chief librarian. Since the chief librarian or director heads a major academic unit, he should have the rank of a dean in a university.

\section{Appendix I. Criteria for Evaluation OF Librarians}

The library faculty shall be evaluated on the basis of truly academic criteria such as are used for the classroom faculty. However, some of these criteria need to be carefully defined in terms of professional librarianship, and the emphasis given to the various factors will vary among different types of work. These criteria, not necessarily in order of relative importance, are as follows:

\section{Teaching or Research Success}

Teaching shall be interpreted to mean the kind of teaching, either group or individual, direct or indirect, a professional librarian does. Examples of teaching activity by librarians: teaching formal classes, lectures to classes, instructing library school students, orientation lectures or tours, guidance (vocational and otherwise), advisory work, aiding students to find and use information, certain reference service, promoting cultural and recreational reading, aiding the faculty in using library resources effectively to supplement, enrich, and im- 
prove teaching, instructing in research methods, etc.

The librarian's own job is a full-time teaching responsibility of a special kind; if he teaches formal classes he should receive additional compensation. It is almost impossible for him to take time off from his library duties to compensate for the extra work that classroom teaching entails. It should be noted also that many librarians have a dual responsibility: for keeping up in a subject field, as well as in professional librarianship. This too differs from classroom faculty interests.

In the technical (bibliographical) services, research and organizational abilities become dominant factors. Certain forms of teaching are, however, a recurring and often uncredited part of the total activity in the area. Informational or advisory in nature, and carried on with library and faculty colleagues as well as with students, such teaching is most often referred to as assistance in:

(1) exploitation of bibliographies, sources of trade information, identification of elusive or erroneous titles, binding criteria, etc.; (2) effective use of the card catalog, serials record, etc.; (3) interpretation of classification system in use.

Success in the above should be rated on: (1) professional knowledge, e.g., bibliographies, structure of card catalog, etc.; and (2) ability to communicate such knowledge to library users in a manner which will increase the user's comprehension of the scope and limitations of the various sources of information and of appropriate techniques for their effective use.

Research success in technical services is based upon four broad areas of competency: (1) ability to identify or describe adequately the bibliographical units constituting the principal professional activity; (2) subject knowledge of breadth and depth adequate for quick comprehension of content and transla- tion into the notation of the classification schedules; (3) extensive knowledge of appropriate sources for further information, either bibliographical or of subject; and (4) sufficient familiarity with current trends in the various subject fields properly to relate new developments to older materials already classified and to adjust, or supplement, subject headings as desirable or necessary. (This familiarity is dependent on extensive reading in the subject and is sometimes supplemented by contact with research faculty in the subject.)

Success in the above is not immediately apparent. Professional-bibliographical ability is perhaps the obvious; clues as to subject competency may be gained from library and faculty colleague satisfaction in locating needed, or desired, material. Dissatisfaction is voiced more frequently than satisfaction and must be evaluated as either failure in communication or as unsatisfactory performance.

Continuing in technical services, research ability in the sense of scientific attitude and consequent action is of the utmost importance in this area. Operational, or action, research can be carried on by the individual as well as by the department or technical services area as a whole. Rating could be based on (1) knowledge of professional techniques, (2) level of intelligence (skill) in application, (3) efficiency of work organization, and (4) recognition of need for, and testing of, new patterns of work organization, either individual or departmental.

\section{Administrative Success}

For certain librarians with considerable administrative responsibility, administrative qualities must weigh more heavily than teaching qualities. Some of the factors in evaluating administrative success are over-all success of the unit, cooperativeness with library and subject field administrators and faculty, efficiency of the library, morale of the staff, fair- 
ness, decisiveness, imaginativeness, judgment, self-control, etc. These factors are similar to those which determine the success of the head of a classroom teaching department.

\section{SCHOLARSHIP AND SCHOLARLY INTERESTS}

As members of the faculty librarians must be aware of the importance of this traditional measure as an indication of professional competence, freshness, and vigor, and of the contribution that continuing scholarship makes to the individual's work. Such activity might be either in library science or the subject field. However, librarians work thirty-nine hours a week, eleven months a year, and during most of the holiday vacations, and therefore have less time for such activity than their classroom colleagues.

The following might be considered as measures of scholarly and professional vigor: research of national interest undertaken and published; reports of significant developments, additions, exhibits, experiments, or news written and published; editorship of professional publications; preparation of scholarly exhibits; administrative research (controlled experiment or search of literature) directed toward improving the library's services; bibliographical research for local or other purposes, including preparation of subject reading lists and lists of new publications; visits to other libraries to become familiar with their. resources and methods of doing their work-especially when directed toward finding answers to one's own problem areas; taking classes in library school or subject department; attending professional meetings or conferences; etc. This criterion is closely related to professional activity. Note that not all scholarly work is published.

Comparisons between classroom teaching staff and professional library staff under present conditions, as to research and publication, is unrealistic because of differences in free time available. Despite the broad definition of research applicable to the library's special activities, more time for research should be provided if possible.

Library administrators should explore methods of providing more time for research and publication. Various suggestions are: (1) create some research-librarian posts, interchangeable among regular librarians who may wish to follow up problems arising in their work, or perform some pure research studies; (2) provide a reserve or emergency staff who might substitute for a librarian engaged in a research project; (3) provide larger staffs, with each librarian given some free time for such activities; (4) greater use of sabbatical leaves; (5) establish institutional journals, perhaps with primary emphasis on acquisitions; etc.

Whereas colleges often are not interested in research capacity and activity, universities always tend to stress research in appointments and promotions. Research is the only tangible evidence of originality and continuing scholarly interests and has come to be stressed because better measures are lacking.

\section{Professional and Community Interest}

Librarians also must be evaluated according to activities in and contributions to the library profession, the university academic community, and the university library. Professional activity also is one measure of professional interest and standing. Factors include: membership in professional and subject field associations; activity in local, state, and national library organizations; participation in university activities; promotion of librarianship in the state or nation; active membership on committees; preparing and delivering papers; and participation in extracurricular activities that further the welfare of the university, library, or community. Taking classes in library school also is a desirable professional act. Membership in social clubs should not be discouraged but usually does not con- 
tribute to the advancement of the university or library.

It is noted that lack of adequate travel allowances militates against attendance at and participation in professional meetings in many libraries. This condition should be acknowledged, taken into account, and corrected as rapidly as possible.

\section{Educational Attainment}

The library field might well be compared with such fields as art, music, and engineering, where the doctorate, although offered, is a rarity. Years of professional and subject-field training should be the base, rather than the degree, plus some weight for experience in varied situations. However, it is recognized that the actual degree itself also must be considered, even as in art, music, and engineering.

Since librarians must possess competence both in library science and usually in one or more subject fields as well, continuing education through the taking of formal courses is quite desirable. They should be given special consideration for such purposes, and encouraged by appropriate recognition and reward.

\section{READING}

Since all librarians deal fundamentally with books, or more properly with recorded information, it is essential that they maintain competence in librarianship and in the subject field or fields appropriate to their activity through wide and consistent reading of books, journals, and reviews. This activity is essential to sound performance in both readers' services and technical services activities.

\section{Length of Service at Present Rank}

Years of service at present rank should have bearing on promotion, but no more than is true of the teaching faculty. However, there seems to be no reason why librarians cannot become full professors if they meet standards of successful performance, administrative success, contributions to scholarship, educational attainment, and activity in professional, university, and community affairs. This should be true irrespective of whether the library unit in which they work is large or small, or whether the major share of their duties consists of teaching, research, or administration.

It is noted that where faculty status has been in effect a relatively short time, the distribution of librarians among different ranks in many universities tends to be poor. A better distribution among the intermediate and upper ranks should be effected as rapidly as possible. Persons qualified for higher rank already on the staff should be promoted in order of merit and tenure as rapidly as budgetary considerations allow.

\section{Personality}

Good personality is essential to successful performance of library tasks, affecting not only successful relations and work with the library's clientele and success in administration but also relations with co-workers and staffs in other departments. Some aspects of personality are covered in preceding paragraphs, but this factor is important enough to justify separate mention. Good personality cannot be defined readily, but is recognized easily.

\section{Outstanding Achievement}

Outstanding achievement in any area should be recognized and considered, the same as for the classroom faculty.

\section{Appfidix II. Procedures for Evaluation OF Libraries}

These criteria for promotion in rank or salary should be used as appropriate to the individual person's duties. Judgment should be by persons in the position to know. For a library assistant, these should include his librarian, the 
assistant director, the assistant librarian for personnel (if any), and the director. For a departmental librarian, the head of the college or department principally served, or the chairman of the departmental library committee also should be consulted. Other persons may be called upon for advice, but in general the success of the librarian shall be evaluated by his superior officers rather than by his colleagues.

These evaluations should be made annually on a systematic basis, including all qualified professional librarians, at the time of considering the budget for the succeeding year. Each librarian should submit on call a record of activ- ities of himself and his staff; this would have to precede the date of the annual report. As to newly appointed staff members, any suggestions for improvement received in the evaluation process should be passed along to the new appointee by his superior officers.

It should be noted that all evaluation may be conducted informally and that no specific weights can be attached to any of the various criteria. The criteria applicable to that individual should be used in evaluating his work. However, some university administrations require brief formal statements in justification of any change in rank or salary for any individual.

\section{Reserve Fund at Columbia}

COLUMBIA UnIVERSITY's trustees have established a reserve fund of $\$ 500,000$ for purchasing and processing books for the university libraries. The fund, which supplements the library operating budget, is to be used over a period of several years. Perhaps as much as 60 per cent of the funds will be used to extend selectively the depth and breadth of the collections in the traditional subject fields, with special emphasis on publications missed in the recent past because of budgetary limitations.

About 10 per cent of the funds will be used to strengthen Columbia's basic resources which are used in support of the teaching and research activities of the various area institutes. Another portion, probably less than 10 per cent, will be used to obtain additional copies of items which are required in support of the instructional program at all levels and in all divisions in the university.

Finally, and perhaps most important, as much as 20 per cent of the reserve funds will be used to inaugurate what must become a continuing program of preservation of important items in the collections. Publications of sufficient importance will be given special treatment designed to retard deterioration or will be replaced by microfilm copies, or copies created by other means. Effective action is needed now if the investment incurred in developing a major research collection is to be safeguarded for the use of scholars who will be working in the not-too-distant future. 